\title{
Maternal Chronic Stress Induces Premature Telencephalic Vesicles Development
}

\author{
El Estrés Crónico Materno Induce el Desarrollo Prematuro de la Vesícula Telencefálica \\ "María Teresa Mugnaini; "Carlos Alberto Soñez; *Alicia Nélida Rolando; "María Cristina Romanini; "Aída Andrea Bozzo; \\ "Isabel Cecilia Pastorino; ${ }^{* *}$ Héctor Fernando Gauna \& ${ }^{* * *}$ Dante Agustín Paz
}

MUGNAINI, M. T.; SOÑEZ, C. A.; ROLANDO, A. N.; ROMANINI, M. C.; BOZZO, A. A.; PASTORINO, I. C.; GAUNA, H. F. \& PAZ, D. A. Maternal chronic stress induces premature telencephalic vesicles development. Int. J. Morphol., 24(4):525-530, 2006.

SUMMARY: Exposure to physical or psychological stress causes brain damage ranging from minimal behavioural alterations to different neurodegeneration degrees implying the overproduction of oxidative-nitrosative compounds, apoptosis and cell proliferation. In the present investigation, we have analysed the effect of the chronic stress by immobilisation applied to pregnant rats over the forebrain development of the embryos. The morphometric analyses showed an accelerated evagination of the telencephalic vesicles in 12 days old fetus from stressed mothers. The forebrain perimeter and the thickness showed significative differences in relation to age-matched controls. This stress effect seemed reversible during subsequent gestational stages. This is the first work showing a transient acceleration in the development induced by the gestational stress. Our model provides a new tool for studying the effect of the stress on the development.

KEY WORDS: Telencephalic vesicle; Chronic stress; Morphometric analysis; Rats.

\section{INTRODUCTION}

The development of an organism is subjected to complex environmental influences. Today, genes and environment are no considered to exert separate influences, and development is viewed not as a gradual elaboration of an architectural plan pre-configured in the genes, but rather as a dynamic interdependency of genes and environment. This is characterized by a continuous process of interaction between these two factors in a place- and time- specific manner, involving short- and long-term information storage, whereby genetic and epigenetic processes become represented in the evolving structural and functional design of the organism at every step of development (Wadhwa $e t$ al., 2001).

If the nature of the environment is perceived to be stressful or hostile, it may promote developmental processes that result in deleterious short- and/or long-term consequences for health. Several studies have provided powerful evidence to support a causal role for prenatal stress on alterations in the brain morphology and function (cognition, emotionality, and behavior) (Lemaire et al., 2000).
The prenatal stress results in an enhanced production of stress hormones by the mother during critical periods of fetal brain development and provokes a definitively longer corticosterone response in the offspring.

In the last few years, several reports indicated that long-lasting stress affects synaptic plasticity, dendritic morphology, and neurogenesis (reviewed by Weinstock, 2001) and induces both clinical and anatomical features of neurotoxic damage in humans, i.e. posttraumatic stress disorder (Sapolsky, 1996).

The precise mechanisms by which stress induces brain damage are still a matter of debate. Some results have demonstrated the neurotoxic action of glutamate and other excitatory amino acids, mainly through the NMDA receptor and the potentiation of their effects by glucocorticoids (Kim et al., 1996). Moreover, a sustained overproduction of nitric oxide via the inducible nitric oxide sintase expression have been implicated in the pathogenesis of stress-induced brain injury (Olivenza et al., 2000).

\footnotetext{
Biología Celular y Embriología, Dpto. de Anatomía Animal. Facultad de Agronomía y Veterinaria. Universidad de Río Cuarto, Argentina.

* Fisiología, Dpto. de Biología Molecular. Facultad de Ciencias Exactas, Fisico-Químicas y Naturales. Universidad de Río Cuarto, Argentina.

**** Instituto de Fisiología, Biología Molecular y Neurociencias (IFIBYNE - CONICET) and Depto. Biodiversidad y Biología Experimental. Facultad de Ciencias Exactas y Naturales. UBA, Argentina.

This work was supported by CONICET (PIP 2309 and PIP 3089) and SECYT-UNRC (PICTO-UNRC 01-11434), Argentina.
} 
Other molecules, related with the cellular proliferation and cell damage, such us growth factors, cytokines and reactive oxygen species (ROS) has been implicated in the stress neuropatogenesis (rewieded in Pacák \& Palkovits 2001).

In spite of a number of biochemical and molecular analysis of the stress effects on the neural differentiation, there are few works relating the mother stress and morphological alterations during the embryo development.

The developmental period extending from neural groove to neural migration onset is of critical importance for subsequent neural development, as events leading to neurulation and cephalization occur during this period, together with active cell division and commitment of cells to neural or glial lineage.

Morphological differentiation of the cerebral hemispheres is dependent on a combination of cell proliferation and cell death. The early vesicles formation during the telencephalic process is a critical period step in the cerebral cortex formation and a target of different neurotoxicological compounds. This period seems especially sensitive to maternal and environmental factors including ethanol (Brown et al., 1979) caffeine (Sahir et al., 2000) cocaine and retinoic acid (Gressens et al., 1992) and others. The aim of this study was to analyze whether the chronic stress applied to pregnant rats affects morphological parameters in the forebrain during the development of the fetus. Previously results from our laboratory showed that immobilization stress in pregnant rats, when applied during three times a week, produce a significant alterations both in the corticosterone levels as well as in different pituitary hormones (Romanini et al., 1999; Rodriguez, 2000). In the present morphometric analysis we found an accelerated development in the telencephalic vesicles in the 12 days embryos from stressed mothers when compared with agematched controls.

\section{MATERIAL AND METHOD}

Adults Wistar, rats weighing 225-250 g, at the beginning of the experiment were used. The rat were housed individually under standard conditions of temperature and humidity and a $12 \mathrm{~h}$ light/dark cycle (light on at 7,30 a.m.) with free access to food and water.

Estrus was determined by vaginal smears, and the mating was confirmed by the presence of sperm in vaginal smears the morning after females had been caged overnight with adult males. These diagnostics defined the $1^{\text {st }}$ day of gestation.
Immobilization stress. Beginning in the $4^{\text {th }}$ day of pregnancy, the female rats were exposed to stress for $45 \mathrm{~min}$ every other day at different time of the day in order to avoid an adaptive habituation (Gómez et al., 1996). Immobilization was performed using a rodent restrainer (Martí et al., 1999 and Olivenza et al.). Control animals were not subjected to stress but were accustomed to handling. The guidelines for the care and use of animals approved by ours institutions were follow according to principles of laboratory animal care (NIH publication 8523, revised 1985 http://www.nih.gov/ sigs/bioethics).

Animals were killed on the days 12, 15, 17 and 21 of pregnancy by decapitation.

From each uterine horn 3 fetus were selected for the further histological processing. We used a total of 15 control and 15 stressed fetus of 12 days of each gestation age.

Freshly removed fetus were fixed in Bouin's liquid, embedded in paraffin and serial sagital sections of $7 \mu \mathrm{m}$ were cut and placed on silanized glass slides.

The stereological study was performed with an automatic image analyzer (VIDAS 2.5, Kontron Electronik, Germany). The images were obtained by a Zeiss Axiophot microscope attached with a digital camera.

Five parameters were measured: 1) the olfactory placodeal area; 2 ) the forebrain (procencephalon) area; 3 ) the forebrain perimeter; 4) the thickness of the forebrain wall and 5) the superficial density (perimeter/area) of the forebrain (Fig. 1).

Data were analyzed by the t' student test comparing fetus from stressed mothers with those from controls mothers.

\section{RESULTS AND DISCUSION}

In order to evaluate the evolutive development of CNS and their components, two structures closely related due to early interactions were selected: the telencephalic vesicles and the olfactory placodes (De Carlos et al., 1995). The comparative analyzes of the different parameters (see methods) showed a significative difference $(\mathrm{p}<0.05)$ in the forebrain area and thickness of the forebrain between stressed and control fetus (Fig. 2). The coefficient of the analyzed parameters in relation to the area occupied by the olfatory placode $(2 / 1 ; 3 / 1 ; 4 / 1)$ showed significative differences $(\mathrm{p}<$ 0.01 ) being the fetus from stressed mothers greater than the controls fetus (Fig. 3). The coefficient 5/1 (superficial density) did not show differences (Fig. 3). 


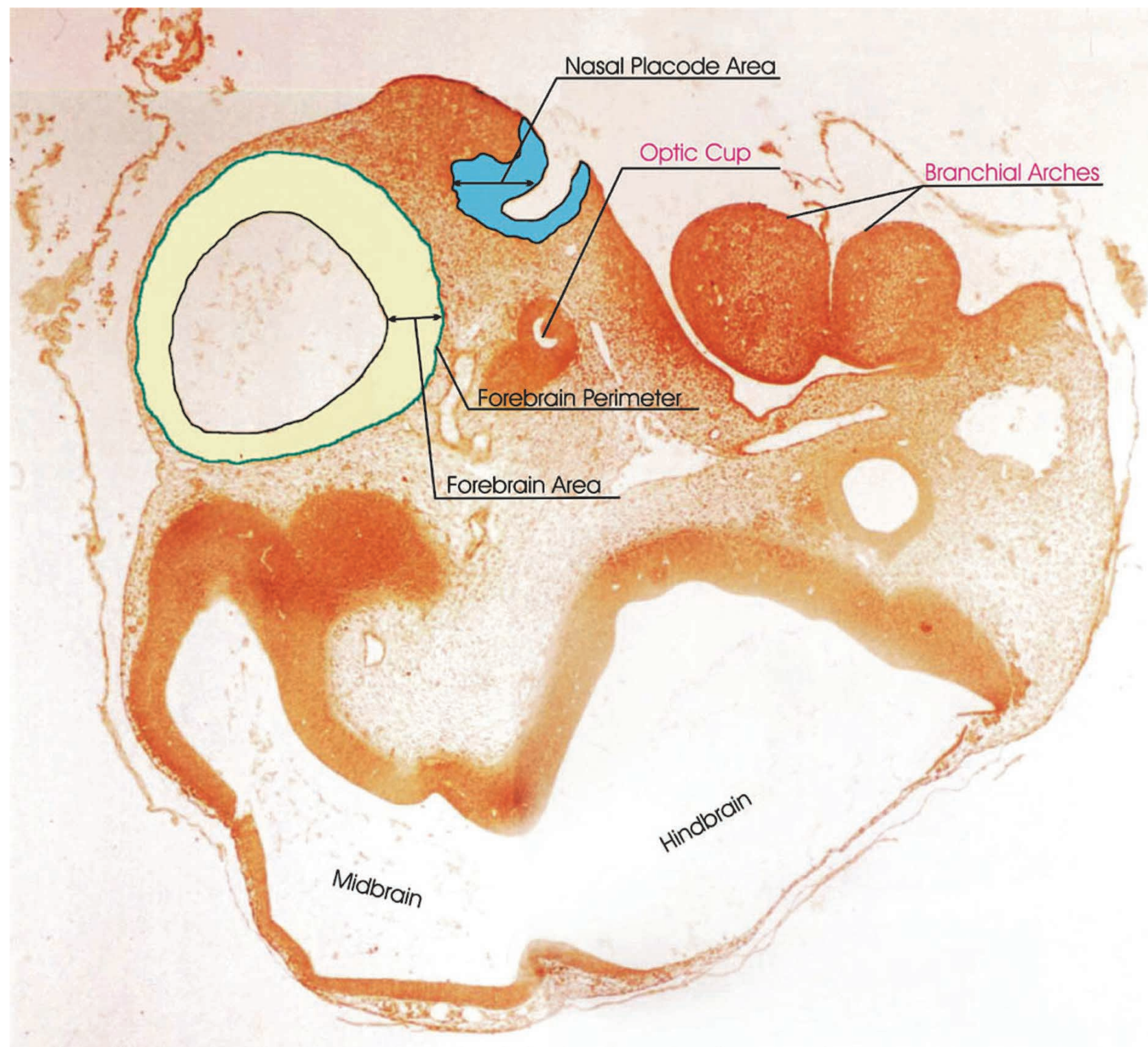

Fig. 1. Parasaggital section of a 12 days embryo showing the different area and perimeter analyzed. Embryos were serially sectioned and the following measures were taken: 1) olfactory area (blue); 2) forebrain (procencephalon) area (yellow); 3) forebrain perimeter (green line); and 4) the thickness of the forebrain area. The superficial density was calculated as the coefficient perimeter/area of the forebrain.

The used quantitative parameters were based on stereological definitions by Weibel $(1979,1980)$ who determined that the area measured in sections of any structure is an estimation of their volume and the perimeter obtained is an estimate of their surface. Volume and surface, as well as, their relation constitute fundamental morphometric variables that help to evaluate possible alterations of the fetus under experimental conditions.

Of all the variables measured in this study, the area, the perimeter and the thickness are structural size varia- bles while the superficial density (perimeter/area) is a form variable. Our results showed that the stress administrated to pregnant mothers caused an increase of size variables but not in the form variables in the fetus (Fig. 1).

The variations caused by IMO stress might be due to several factors: 1) increase in the migration velocity or number of cells originated in the olfactory placode (see De Carlos et al.). 2) Increase in the expression of trophic factors like the neurotrophin brain derived 


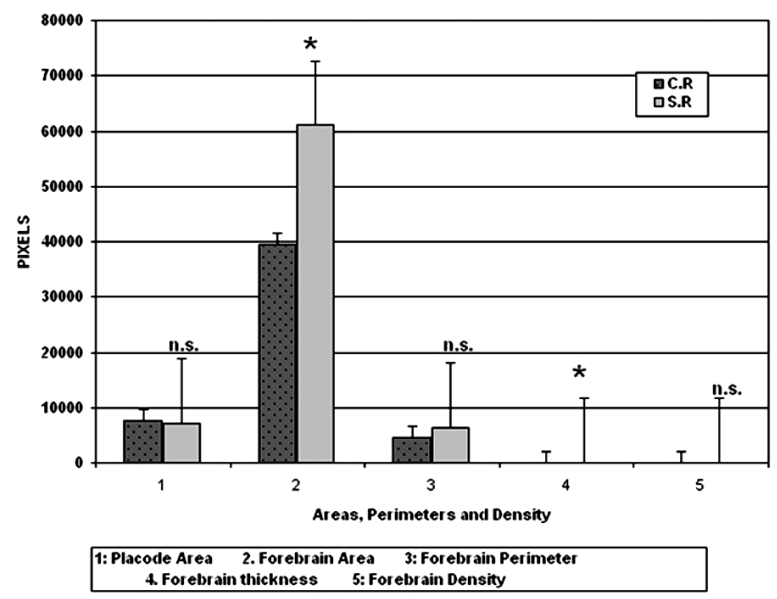

Fig. 2. Stereological morphometric comparison of the different measures analyzed in 12 days old rat embryos from stressed mothers (S.R.) and Control (non-stressed mothers) (C. R.). In the x-axis. 1. Olfactory placodal area; 2. forebrain area; 3 . forebrain perimeter; 4. forebrain thickness and 5. forebrain density. The values are expressed as means \pm S.E.M; asterisks indicate differences from controls $(* \mathrm{p}<0.05)$. n.s. statistically non significant differences with the control in the t' student test.

neurotrophic factor (BDNF), which may induce an increased neuronal survival. 3) Cellular death program (apoptosis), which is one mechanism present in the embrionary neural tissue remodelation (Holcomb et al., 1995 ) inhibited. We do not know how is the mother stress affecting to the fetus.

Recently the vascular endothelial growth factor (VEGF) has been implicated in the neuronal proliferation and survival reducing the cell death in the developing mouse brain cortex (Ogunshola et al., 2002). Since the nitric oxide (NO) increases the VEGF production (Jozkowicz et al., 2001) a possible role of increased VEGF production, via NO, may be responsible of the increased telencephalic volume in fetus of stressed mothers.

In stress the glucocorticoids produces a physiological transient vasoconstriction at placental level mediated by the secretion of corticotropin releasing hormone $(\mathrm{CRH})$ and the mayor effectors of stress response including catecholamines, oxitocin, angiotensin II, both forms of interleukin I and hipoxia (Petraglia et al., 1987).

This phenomena is followed by an transient hipoxic state. This sublethal hipoxia promotes mitotic activity in telencephalic development without a variation

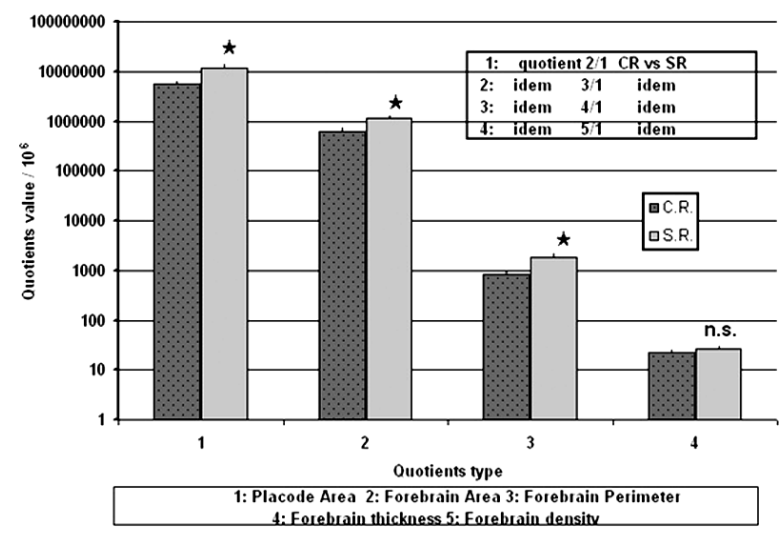

Fig. 3. Comparative analysis of the different quotients analyzed (see Material and Method) in 12 days old rat embryos form stressed mothers (S.R.) and controls mothers (C.R.). In the $\mathrm{x}$-axis the different quotients. 1. Forebrain area / Olfactory placode area; 2. Forebrain perimeter / Olfactory placode area; 3 . Forebrain thickness / Olfactory placode area; 4. Forebrain density / Olfactory placode area. In the Y-axis quotients value /106 The values are expressed as means \pm S.E.M; asterisks indicate differences from controls $(* * p<0.01)$. n.s. statistically non significant differences with the control in the t' student test.

in the apoptotic index (Bossenmayer-Pourié et al., 1999).

Other possibility is related with a surge of ROS induced by the IMO stress, which could by both the increment oxidative metabolism and superoxide generation. The relative immature in the free radical scavenging system at day 12 of gestation, as well as, inhibition of the free scavenging patways could be alterating the forebrain development as was observed in the diabetic pregnancy (Chang et al., 2003).

In conclusion, the present study showed an increased volume of the telencephalic vesicles in 12 days old rat fetus from stressed mothers. This increment is transient because no differences between 15 old fetus from stressed and control mothers was observed. Our model may be useful in order to identify genes and transduction pathways involved in the early response of the developing CNS to stress.

\section{ACKNOWLEDGEMENTS}

The authors would like to gratefully acknowledge the invaluable contribution of Lic. Rubén Dezi and the technical support of Mario Lazarte. 
MUgnaini, M. T.; SOÑEZ, C. A.; ROLANDO, A. N.; ROMANINI, M. C.; BOZZO, A. A.; PASTORINO, I. C.; GAUNA, H. F. \& PAZ, D. A. El estrés crónico materno induce el desarrollo prematuro de la vesícula telencefálica. Int. J. Morphol., 24(4):525-530, 2006.

RESUMEN: La exposición a diferentes estresantes físicos y/o psicológicos causa daño cerebral, que se manifiesta en alteraciones comportamentales mínimas hasta diferentes grados de neurodegeneración, y que implican la sobreproducción de compuestos nitrosativosoxidativos, apoptosis y proliferación celular. En el presente trabajo hemos analizado el efecto del estrés crónico por inmovilización, sobre el desarrollo embriológico del cerebro anterior en fetos de ratas preñadas. El análisis morfométrico estereológico demostró que en los fetos de 12 días de gestación de madres estresadas muestran un aumento del tamaño de la vesícula telencefálica. El perímetro y el espesor del cerebro anterior demostraron diferencias significativas en relación a los controles de la misma edad gestacional, pero, no fue así con su forma. Este efecto provocado por el estrés crónico se podría considerar reversible en los estadíos gestacionales subsecuentes. Es el primer trabajo que demuestra una considerable aceleración del desarrollo del sistema nervioso central inducido por el estrés gestacional. Nuestro modelo provee una nueva herramienta para los estudios de los efectos del estrés durante el desarrollo embriológico.

PALABRAS CLAVE: Vesícula telencefálica; Estrés crónico; Análisis morfométrico; Ratas.

\section{REFERENCES}

Bossenmeyer-Pourié, C.; Chihab, R.; Schroeder, H. \& Daval, J. L. Transient hipoxia may lead to neuronal proliferation in the developing mammalian brain: from apoptosis to cell cycle completion. Neuroscience, 91:221-31, 1999.

Brown, N. A.; Goulding, E. H. \& Fabro, S. Ethanol embryotoxicity: direct effects on mammalian embryos in vitro. Science, 206:573-7, 1979.

Chang, T. I.; Horal, M:; Jain, S. K.; Wan, F.; Patel, R. \& Loeken, M. R. Oxidant regulation of gene expression and neural tube development: insights gained from diabetic pregnancy on molecular causes of neural tube defects. Diabetologia, 46:538-45, 2003.

De Carlos, J. A.; López-Mascaraque, I. \& Valverde, F. The telencephalic vesicles are innervated by olfactory placodederived cells: a possible mechanisms to induced neocortical development. Neuroscience, 68:1167-78, 1995.

Gómez, F.; Lahmame, A.; De Koet, E. R. \& Armario, A Hypothalamic-pituitary-adrenal response to chronic stress in five imbred rat strains: differential responses are mainly located at the adrenocortical level. Neuroendocrinol., 63:327-37, 1996.

Gressens, P.; Gofflot, F.; Van Maele-Fabry, G.; Misson, I. P. ; Gadisseux, I. F. \& Evrard, P. Early neurogenesis and teratogenesis in whole mouse embryo cultures. Histochemical, immunocytological and ultrastructural study of the premigratory neuronal-glial units in normal mouse embryo and in mouse embryos influenced by cocaine and retinoic acid. J. Neuropathol. Exp. Neurol., 51:206-19, 1992.
Holcomb, J. D.; Mumm, J. S. \& Calof, A. L. Apoptosis in the neuronal lineage of the mouse olfactory epithelium: regulation in vivo and in vitro. Dev. Biol., 172:307-23, 1995.

Jozkowicz, A.; Cooke, J. P.; Guevara, I.; Huk, I.; Funovocs, P.; Pachinger, O.; Weidinger, F. \& Dulak, J. Genetic augmentation of nitric oxide synthase increases the vascular generation of VEGF. Cardiovasc. Res., 51:77383, 2001.

Kim, J. J.; Foy, M. R. \& Thompsom, R. F. Behavioral stress modifies hippocampal plasticity through N-methyl-Daspartate receptor activation. Proc. Natl. Acad.Sci. USA, 93:4750-3, 1996.

Lemaire, V.; Koehl, M.; Le Moal, M. \& Abrous, D. N. Prenatal stress produces learning deficits associated with an inhibition of neurogenesis in the hippocampus. Proc. Natl. Acad. Sci. USA, 97:11032-7, 2000.

Martí, O.; Andrés, R. \& Armario, A. Defective ACTH response to stress in previously stressed rats: dependence on glucocorticoid status. Am. J. Physiol., 277:869-77, 1999.

Ogunshola, O. O.; Antic, A.; Donoghue, M. J.; Fan, S. Y.; Kim, H.; Stewart, W. B.; Madri, J. A. \& Ment, L. R. Paracrine and autocrine functions of neuronal vascular endothelial growth factor (VEGF) in the central nervous system. J. Biol. Chem., 277:11410-5, 2002.

Olivenza, R.; Moro, M. A.; Lizasoain, I.; Lorenzo, P.; Fernández, A. P.; Rodrigo, J.; Boscá, L. \& Leza, J. C. Chronic stress induces the expression of inducible nitric oxide synthase in rat brain cortex. J. Neurochem., 74:785-91, 2000. 
Pacák, K. \& Palkovits, M. Stressor specificity of central neuroendocrine responses: Implications for stress-related disorders. Endocrine Rev., 22:502-48, 2001.

Petraglia, F.; Sawchenko, P. F.; Rivier, J. \& Vale, W. Evidence for local stimulation of ACTH secretion by corticotropinreleasing factor in human placenta. Nature, 328:717-9, 1987.

Rodriguez, N. Efectos del estrés crónico en ratas gestantes sobre la madurez sexual de las crías macho (in Spanish). $\mathrm{Ph}$ D thesis. Universidad de Rio Cuarto. Argentina, 2000.

Romanini, M. C.; Rodriguez, N.; Mugnaini, M. T.; Rolando, A. N.; Soñez, C. A \& Gauna, H. Effects of chronic stress by immobilization on the plasmatic levels of corticosterone in pregnant rats. Biocell., 23:14 (abstract), 1999.

Sahir, N.; Bahi, N.; Evrard, P. \& Gressens, P. Caffeine induces in vivo premature appearance of telencephalic vesicles. Dev. Brain Res., 30:213-7, 2000.

Sapolsky, R. M. Stress, glucocorticoids, and damage to the nervous system: The current state of confusion. Stress, 1:1-19, 1996.

Wadhwa, P. D.; Sandman, C. A. \& Garite, T. J. The neurobiology of stress in human pregnancy: implications for prematurity and development of the fetal central nervous system. Prog. Brain Res., 133:131-42, 2001.

Weibel, E. R. Stereological Methods Practical Methods for Biological Morphometry. Academic Press, 1979.

Weibel, E. R. Stereological Methods. Theoretical Foudations. Academic Press, 1980.

Weinstock, M. Alterations induced by gestational stress in brain morphology and behavior of the offsprings. Progress Neurobiol., 65:427-51, 2001.
Correspondence to:

Dra. María Teresa Mugnaini.

Departamento de Anatomía Animal. Facultad de Agronomía y Veterinaria. Universidad Nacional de Río Cuarto. (5800) Río Cuarto. Pcia. de Córdoba. ARGEX TIN $\mathcal{A}$

$\mathcal{F a x}: 543584680280$

E-mail:mmugnaini@ayv.unrc.edu.ar

Received: 14-06-2006

Accepted: 22-09-2006 